\title{
Novel Acinetobacter parvus HANDI 309 microbial biomass for the production of $N$-acetyl- $\beta$-D-glucosamine (GlcNAc) using swollen chitin substrate in submerged fermentation
}

\author{
Tae II Kim ${ }^{1 \dagger}$, Kwang Seok Ki ${ }^{1}$, Dong Hyun Lim ${ }^{1}$, Mayakrishnan Vijayakumar ${ }^{1 *}$, Seong Min Park ${ }^{1}$, Sun Ho Choi ${ }^{1}$, \\ Ki Young Kim², Seok Ki Im and Beom Young Park
}

\begin{abstract}
Background: $N$-acetyl- $\beta$-D-glucosamine (GlcNAC) ${ }_{6}$ is extensively used as an important bio-agent and a functional food additive. The traditional chemical process for GlcNAc production has some problems such as high production cost, low yield, and acidic pollution. Therefore, to discover a novel chitinase that is suitable for bioconversion of chitin to GlcNAc would be of great value.

Results: Here, we describe the complete isolation and functional characterization of a novel exo-chitinase from Acinetobacter parvus HANDI 309 for the conversion of chitin. The identified exo-chitinase mainly produced $\mathrm{N}$-acetylD-glucosamine, using chitin as a substrate by submerged fermentation. The A. parvus HANDI 309 biofuels producing exo-chitinase were characterized by TLC, and was further validated and quantified by HPLC. Furthermore, the optimal temperature and $\mathrm{pH}$ for the exo-chitinase activity was obtained in the culture conditions of $30^{\circ} \mathrm{C}$ and 7.0 , respectively. The maximum growth of the stationary phase was reached in $24 \mathrm{~h}$ after incubation. These results suggest that $\mathrm{A}$. parvus HANDI 309 biofuels producing exo-chitinases may have great potential in chitin to $\mathrm{N}$-acetyl-D-glucosamine conversion.

Conclusions: The excellent thermostability and hydrolytic properties may give the exo-chitinase great potential in chitin to GlcNAc conversion in industry. This is the first report that A. parvus HANDI 309 is a novel bacterial strain that has the ability to produce an enormous amount of exo-chitinase-producing bio-agents in a short time on an industrial scale without any pretreatment, as well as being potentially valuable in the food and pharmaceutical industries.
\end{abstract}

Keywords: Chitinase, Acinetobacter parvus, Chitin, N-acetyl-D-glucosamine, Feces, Calves

\section{Background}

Chitin is the secondmost abundant, readily obtained, renewable and high molecular weight natural polysaccharide, consisting of $\beta$-1,4-linked $N$-acetyl-D-glucosamine

\footnotetext{
*Correspondence: marulbiochem@rediffmail.com

tTae II Kim and Mayakrishnan Vijayakumar contributed equally to this work

${ }^{1}$ Dairy Science Division, National Institute of Animal Science, Rural Development Administration, \#114, Shinbang 1Gil, Seonghwan-eup, Seobuk-gu, Cheonan-si, Chungcheongnam-do 331-801, South Korea Full list of author information is available at the end of the article
}

(GlcNAc) with high similarity to cellulose, except that the glucose residue with hydroxyl groups is replaced by an acetylated or deacetylated amino group. It is dispersed in various locations, including snails, crustaceans, insects, vertebrates, plants and microorganisms [1]. For example, shellfish contain $20-58 \%$ of chitin, while fungal cell walls consist of $22-40 \%$ of chitin [2, 3]. In recent years, numerous researchers have been reported the use of chitin and related materials in various fields, including heavy metal recovery, drug delivery, wound healing, dietary fibre, agriculture andthe environment [4]. The natural 
biopolymer of chitin is composed of biological molecules such as carbohydrates, lipids, proteins and pigments, as well as minerals insoluble in water, or in the majority of organic solvents, so its uptake is not easy. Therefore, chitin demineralization and deproteinization are a vital process to acquire purified chitin. Also, the purification of chitin accomplished by using acids or alkalis has safety and environmental problems [3]. Hence, low-cost chitindegrading enzymes are alternatively used for the production of chitin on an industrial scale.

Chitinases are a group of enzymes (EC.3.2.14) that hydrolyze the chitin to low-molecular-weight oligo and monomeric components and have been shown to be produced by some microorganisms, fungi, insects, higher plants and animals in which they play a significant physiological role depending on their origin [5]. The extracellular chitinase-producing microbes will use chitin or colloidal chitin as a carbon sources for the production of a mixture of chitinases and $\mathrm{N}$-acetylglucosaminidase. These extra cellular chitinases can be classified into two types: intra- and extracellular. Endochitinases play a significant role in the cleavage of chitin to generate multimers of GlcNAc. Extracellular chitinases are mainly involved in producing GlcNAc, chitobiose or chitotriose. Chitinases have huge potential industrial applications, e.g. in the preparation of pharmaceutically relevant chitooligosaccharides and GlcNAc, the preparation of single cell protein (SCP), in cell differentiation, and they are also involved in isolating the protoplasts from fungi and yeast, in chitinous waste treatment, and in the control of malaria transmission [2]. GlcNAc is one of the primary products of enzymatic hydrolysis of chitin.

In recent years, GlcNAc has received more attention, due to its valuable functions in a broad range of fields, including the pharmaceutical and biotechnological industries, and especially in the fermented food industry its use is growing rapidly [6]. Generally, GlcNAc has been commercially produced by the acid hydrolysis of chitin with high concentrations abd high temperatures. However, this development has some demerits, including high cost, low yield and environmental pollution. Moreover, GlcNAcs manufactured by chemical methods limit their applications in the food industry [7, 8]. Hence, the bacteria-produced extracellular chitinase enzymes for nutritional functions can consume chitin as a substrate for the carbon source. Chemically-based pesticides cause longlasting side effects on ecosystems. Therefore, researchers have paid more attention to searching for and developing non-hazardous, eco-friendly options. Such eco-friendly alternatives are considered as biofuels for bio-control agents which will inhibit or kill pests in a biologically safe manner and without producing any environmental pollution [3]. Hence, the present study was performed to characterize GlcNAc-produced chitinolytic chitinase by a novel antibiotic resistance method using Acinetobacter parvus HANDI 309 from the feces of calves. We also optimized the production and growth conditions.

\section{Methods}

\section{Preparation of swollen chitin}

The preparation of swollen chitin followed the method of Monreal and Reese [9]. Briefly, $10 \mathrm{~g}$ of flake chitin was added into $100 \mathrm{~mL}$ of $85 \%$ phosphoric acid at $4{ }^{\circ} \mathrm{C}$ for $48 \mathrm{~h}$. Then, the swollen chitin was precipitated by adding the gelatinous mixture into an excess of cold water. The excess of water was then removed and the precipitate was washed with distilled water until the $\mathrm{pH}$ became neutral.

\section{Microorganism and production conditions of chitinase}

Acinetobacter parvus HANDI 309 was originally isolated and identified from the feces of Korean Native calves, and the culture media was developed by Kim et al. [10]. The isolated culture was inoculated $(50 \mathrm{~mL})$ into culture medium (1 L) containing colloidal chitin agar medium with the following composition: $1 \%$ swollen chitin, $1 \%$ peptone and $1 \% \mathrm{NaCl}(\mathrm{pH} 5.0)$. Then, $1 \mathrm{~mL}$ of the spore suspension was added to $100 \mathrm{~mL}$ of colloidal broth, and incubated in a rotary incubator at $220 \mathrm{rpm}$ and $30^{\circ} \mathrm{C}$ for $120 \mathrm{~h}$. After the incubation period, the culture broth was centrifuged at $10,000 \mathrm{~g}$ and $4{ }^{\circ} \mathrm{C}$ for $20 \mathrm{~min}$. The collected supernatant consisted of crude chitinase which was further used for analysis. The culture supernatant was used for chitinase assay after overnight dialysis against $10 \mu \mathrm{M}$ sodium acetate buffer ( $\mathrm{pH}$ 5.0). Cell growth was also measured at OD $660 \mathrm{~nm}$.

\section{Enzyme activity assay by calorimetric method}

For the determination of chitinase activity, colloidal chitin was used as a substrate. An amount of $0.5 \mathrm{~mL}$ of $1 \%$ colloidal chitin was added to $0.5 \mathrm{~mL}$ of enzyme solution and then the solution was incubated at $45{ }^{\circ} \mathrm{C}$ for $1 \mathrm{~h}$. Next, $3 \mathrm{~mL}$ of 3,5-dinitrosalicyclic acid was added to stop the reaction, followed by incubation at $100{ }^{\circ} \mathrm{C}$ for $5 \mathrm{~min}$. After centrifugation, the level of reducing sugar in the supernatant was carried out by the methods of Miller [11] with some modifications. The absorbance was noted at $540 \mathrm{~nm}$ using a UV spectrometer for the sample and also a blank. For the measurement of enzyme action, serial dilutions of GlcNAc was prepared and used. One millimole of GlcNAc was used as a standard.

\section{Chitinolytic activity by Petri dish method}

The hydrolytic activity of the isolated HANDI 309 bacterial strain from the feces of calves was measured by the serial dilution method and was screened by its capability to produce hydrolytic enzymes using the plate method. 
The sterile culture medium was developed on nutrient agar plates supplemented with $0.1 \%$ colloidal chitin, and $1.5 \%$ agar medium was inoculated with the isolated organism at $30{ }^{\circ} \mathrm{C}$ for $24 \mathrm{~h}$. After the incubation period, $0.1 \%$ Congo red solution was poured over the plate, and the clear zone around the isolates observed after the incubation period is an indication of chitinase enzyme production $[12,13]$.

\section{Molecular identification of $A$. parvus HANDI 309 for the production of chitinolytic enzyme}

The 16S ribosomal DNA gene sequence was performed by method of Thompson et al. [14]. In brief, genomic DNA was isolated from A. parvus HANDI 309 and purified by a Wizard genomic DNA purification kit (Promega, USA). The subsequent genomic DNA amplifications were sequenced with Taq DNA polymerase using the universal primers of 27F (5'-AGA GTT TGA TCA TGG CTC AG-3') and 1429R (5'-GGA TAT TAC GAC TTC TTG$\left.3^{\prime}\right)$. The amplified PCR products were purified by using the Wizard SV Gel and cleanup system (Promega). The purified PCR products were sequenced using an ABI PRISM 3730 DNA analyzer. The results were compared using sequence homology using the ClustalX program of Mega 2 and with the DNA sequence of ribosomal GENBANK using the BLAST program. During the similarity comparison, the sequence required an initial threshold of $99 \%$ homology when compared with the raw sequence.

\section{Analysis of the hydrolytic products of swollen chitin Thin layer chromatography (TLC)}

In a $150-\mu \mathrm{L}$ reaction mixture containing $0.5 \mathrm{~mL}$ of $1 \%$ of the substrate and $0.5 \mathrm{~mL}$ of $A$. parvus HANDI 309 chitinases in $50 \mathrm{mM}$ of phosphate buffer at $\mathrm{pH} 7.0$, those reaction mixtures were incubated at $37{ }^{\circ} \mathrm{C}$ for $12 \mathrm{~h}$. Next, $10 \mu \mathrm{L}$ of the response mixture was transferred to an Eppendorf tube containing $10 \mu \mathrm{L}$ of $0.1 \mathrm{~N} \mathrm{NaOH}$ to stop the reaction, and samples were stored in $-20{ }^{\circ} \mathrm{C}$ until further analysis. Then, $20-\mu \mathrm{L}$ aliquots from the reaction mixture were added to the chromatograph on silica gel plates, with a solvent system containing $n$-propanol, methanol, and ammonia water [7:3:1 (v:v:v)], and the hydrolyzed products were analyzed by spraying the plate with aniline-diphenylamine reagent and baking at $180{ }^{\circ} \mathrm{C}$ using a hot air gun for $3 \mathrm{~min}$.

\section{High-performance liquid chromatography (HPLC)}

Analysis of the hydrolytic products of swollen chitin by A. parvus HANDI 309 extracellular chitinases was carried out by incubating the recombinant enzymes with the swollen chitin. The reaction mixture was added to $50 \mathrm{mM}$ sodium phosphate buffer at $\mathrm{pH}$ 7.0, and incubated at $40{ }^{\circ} \mathrm{C}$ and $1300 \mathrm{rpm}$ for $12 \mathrm{~h}$. After that, $75 \mu \mathrm{L}$ of the response mixture was mixed with $75 \mu \mathrm{L}$ of $70 \%$ acetonitrile to stop the reaction, and then the reaction mixture was centrifuged at $16,100 \mathrm{~g}$ for $10 \mathrm{~min}$ at $4{ }^{\circ} \mathrm{C}$ to remove the undigested swollen chitin. The supernatant was further concentrated until the complete evaporation of the solvent without heating. The remains were dissolved in $20 \mu \mathrm{L}$ of $35 \%$ acetonitrile and the reaction mixture was stored at $-20{ }^{\circ} \mathrm{C}$ until further analysis. The reaction mixture was analyzed by isocratic HPLC at $25^{\circ} \mathrm{C}$ using a Shimadzu 10ATvp UV/VIS HPLC system (Shimadzu, Tokyo, Japan) with a Shodex Asahipack NH2P-50 4E column $(4.6 \mathrm{ID} \times 250 \mathrm{~mm})$. A sample or $20 \mathrm{ml}$ of the reaction mixture was injected into the HPLC using a Hamilton syringe (Hamilton, Bonadzu, Switzerland). The liquid phase consisted of $67 \%$ acetonitrile and $33 \%$ MilliQ water and the flow rate was set to $0.70 \mathrm{~mL} / \mathrm{min}$, with the eluted chitooligosaccharides monitored by reading the absorption at $210 \mathrm{~nm}$.

\section{Production optimization of chitinase produced by $A$. parvus HANDI 309}

Effect of incubation time and cell growth on chitinase activity The effect of incubation time and cell growth on the activity of chitinase by $A$. parvus HANDI 309 was determined by using an inoculated flask containing the isolated culture inoculated in colloidal chitin agar medium, with the following composition (\% $\mathrm{w} / \mathrm{v})$ : colloidal chitin (1), yeast extract (0.1), $\mathrm{K}_{2} \mathrm{HPO}_{4}(0.07), \mathrm{KH}_{2} \mathrm{PO}_{4}(0.03)$, $\mathrm{MgSO}_{4} \cdot 7 \mathrm{H}_{2} \mathrm{O}(0.01)$, and $\mathrm{FeSO}_{4} \cdot 7 \mathrm{H}_{2} \mathrm{O}(0.01)$ at $\mathrm{pH} 7.0$, which was incubated using a rotary shaker at $200 \mathrm{rpm}$ and $30{ }^{\circ} \mathrm{C}$ for $120 \mathrm{~h}$. After that, the culture was centrifuged at 10,000 rpm for $20 \mathrm{~min}$ and the supernatant used for the chitinase activity. For the specific incubation time, the bacterial cells were grown for $120 \mathrm{~h}$. The culture filtrate was harvested every $24 \mathrm{~h}$ and the enzyme production measured.

\section{Impact of temperature and $\mathrm{pH}$ on chitinase activity}

To determine the effect of incubation temperature and time, the incubating culture tryptic soy broth medium was measured at various temperatures $(25,30$ and $35{ }^{\circ} \mathrm{C}$ ) for $24 \mathrm{~h}$ on a shaking incubator (VS-8480SR; Vision Scientific, Korea) at $200 \mathrm{rpm}$. The effect of initial $\mathrm{pH}$ values on the chitinase production was analyzed by the inoculating broth culture medium composed of pancreatic digest of casein, $0.3 \%$ enzymatic digest of soy meal, $0.25 \%$ dextrose, $0.5 \% \mathrm{NaCl}$, and $0.25 \%$ dipotassium phosphate which was adjusted with $0.1 \mathrm{~N} \mathrm{HCl}$ and $0.1 \mathrm{~N} \mathrm{NaOH}$ to various initial $\mathrm{pH}$ of $5-9$ for $24 \mathrm{~h}$ on a shaking incubator (VS-8480SR; Vision Scientific) at $200 \mathrm{rpm}$. Chitinase activity was measured as per the standard protocol, and the unit of chitinase activity was $\mathrm{U} / \mathrm{mL}$. 


\section{Effect of carbon source on chitinase activity}

Four different types of carbon sources, glucose, sucrose, soluble starch and corn flour, were used to determine the impact of carbon sources on extracellular chitinase activity. These results were measured by adding different carbon sources $(1 \% \mathrm{w} / \mathrm{v})$ of supplemented media wihch were inoculated with inoculums $(20 \mathrm{~mL})$ fermented in optimized conditions. The culture medium contained different levels of glucose, which was adjusted to $0.5-2 \%$ on the shaking incubator. Chitinase activity was measured as per the standard protocol, and the unit of chitinase activity was $\mathrm{U} / \mathrm{mL}$. At the same time, the medium without carbon sources was used as a control.

\section{Effect of organic and inorganic nitrogen source on chitinase activity}

To explore the effect of organic and inorganic nitrogen sources on chitinase activity, various organic nitrogen sources $(0.5 \% \mathrm{w} / \mathrm{v})$, such as yeast extract, peptone, soybean flour and dry yeast were used, while the inorganic nitrogen sources $(0.1 \% \mathrm{w} / \mathrm{v})$ were urea, $\left(\mathrm{NH}_{4} \mathrm{Cl}_{2}\right) \mathrm{SO}_{4}$, $\mathrm{NH}_{4} \mathrm{Cl}, \mathrm{KNO}_{3}$ and $\mathrm{NaNO}_{3}$, respectively. The different sources of both organic and inorganic sources inoculated with inoculums were incubated at $\mathrm{pH} 7.0$ and $30{ }^{\circ} \mathrm{C}$ for $24 \mathrm{~h}$ under a shaking condition of $1200 \mathrm{rpm}$. The culture filtrate was used to measure chitinase activity after the incubation time, and the unit of chitinase activity was $\mathrm{U} /$ mole. An appropriate control was used for the study.

\section{Effect of inorganic salts source on chitinase activity}

The influence of various inorganic salts on chitinase activity was determined by inoculating the culture medium which was adjusted with different inorganic salts $\left(1 \%\right.$ w/v) of $\mathrm{NaCl}, \mathrm{K}_{2} \mathrm{HPO}_{4}, \mathrm{MgSO}_{4} \cdot 7 \mathrm{H}_{2} \mathrm{O}, \mathrm{MnSO}_{4} \cdot 5 \mathrm{H}_{2} \mathrm{O}$ and $\mathrm{CaCl}$, and then incubated at $\mathrm{pH} 7.0$ and $30{ }^{\circ} \mathrm{C}$ for $24 \mathrm{~h}$ under a shaking condition of $200 \mathrm{rpm}$. The culture filtrate was used to measure chitinase activity after the incubation time, and the chitinase activity was expressed as $\mathrm{U} / \mathrm{mol}$. An appropriate control was maintained for the above study.

\section{Results and discussion}

In recent years, extracellular chitinases have received more attention due to their potential applications in industry. Therefore, many microbial extracellular chitinases have been isolated and characterized from various sources. However, there has been no previous report on the characterization of GlcNAc ${ }_{6}$ produced by a novel A. parvus HANDI 309 extracellular chitinase from the feces of calves. So far, about 10 morphologically different strains of chitinolytic enzyme-producing bacteria have been isolated from the feces of calves. Among them, $A$. parvus HANDI 309 exhibited the maximum degradation of swollen chitin and provided a clear zone. Therefore, $A$. parvus HANDI 309 was selected for further characterization of extracellular chitinase in the production of GlcNAc and the optimization of the production conditions. Hence, for the first time, we have described GlcNAc 6 produced by a novel $A$. parvus HANDI 309 extracellular chitinase which was more active at $30^{\circ} \mathrm{C}$ and $24 \mathrm{~h}$ at $\mathrm{pH}$ 7.0.

\section{Molecular identification of HANDI 309}

The 16SrRNA sequence analysis of HANDI 309 was performed, and revealed the maximum sequence homology with $A$. parvus (phylogenic tree provided as Additional files $1,2,3,4,5)$. The acknowledged bacterium was Gram-negative, non-fermentative, non-motile and facultative aerobic nature. Numerous study reports on the industrial production of microbial chitinase enzymes are mostly based on the yield and applications. Therefore, this high-yielding extracellular chitinase producing a novel $A$. parvus HANDI 309 has been isolated, identified, genotypically confirmed and deposited in the Korean Agricultural Culture Collection (KACC91499P).

\section{Chitinolytic activity of extracellular chitinase enzyme}

The chitinolytic activity of $A$. parvus HANDI 309 extracellular chitinase was analyzed by using a Petri dish plate assay method. The chitinase hydrolyzed the $0.1 \%$ of swollen chitin in various concentrations after $24-72 \mathrm{~h}$ of growth on Congo red agar supplemented by swollen chitin as a carbon source. It produced a clear zone around the growing bacteria which indicated the chitinase activity (Fig. 1).

\section{Characterization of hydrolysis products by TLC and HPLC}

The accumulated polysaccharides in chitin hydrolyzed by extracellular chitinase enzyme, and their end products of chitooligosaccharide, were identified by TLC as GlcNAc 6

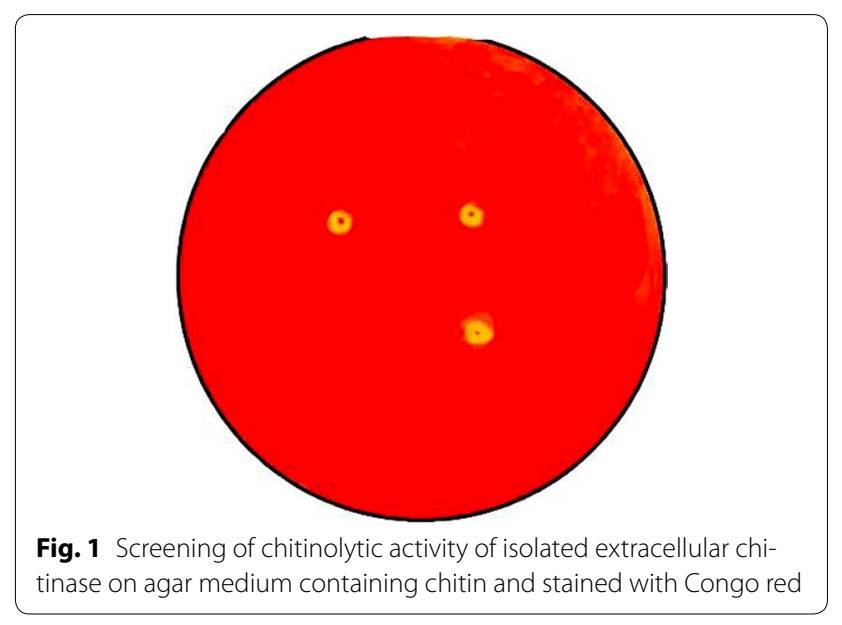


as shown in Fig. 2a. When the chitinolytic enzyme was incubated with swollen chitin, after 24-h experimental periods, GlcNAc 6 was observed as the major end product. The eluted GlcNAc $_{6}$ was further validated and quantified by using HPLC (Fig. 2b). Thus, $A$. parvus HANDI 309 extracellular chitinase is an ideal biocatalyst for microbial degradation and utilization of chitin in an industrial application which can more efficiently use it in bioconversion.

\section{Optimization of extracellular chitinase activity} Effect of chitin and cell growth on chitinase activity

We observed that A. parvus HANDI 309 supports the maximum swollen chitin degradation by the production of extracellular chitinase enzyme in seed culture after $24 \mathrm{~h}$ incubation time (Fig. 3a). Acinetobacter parvus HANDI 309 produced extracellular chitinase showing the highest chitinolytic activity after $24 \mathrm{~h}(2.4 \mathrm{U} / \mathrm{mL})$ which then remained constant up to $96 \mathrm{~h}$ after which we noted the activity of extracellular chitinase enzyme decreased. The reduced activity of chitinase enzyme is due to the inactivation of the secretary machinery of the enzyme, by the lack of nutrients or toxic agents present in the culture medium. This showed that the chitinase production is directly proportional to bacteria growth. From the study, we confirmed that the influence of swollen chitin concentration on the chitinase activity demonstrated that the chitin correlated with the chitin substrate concentration. Hence, the maximum activity was shown at $0.5 \%$ chitin concentration in the culture medium. Our results showed

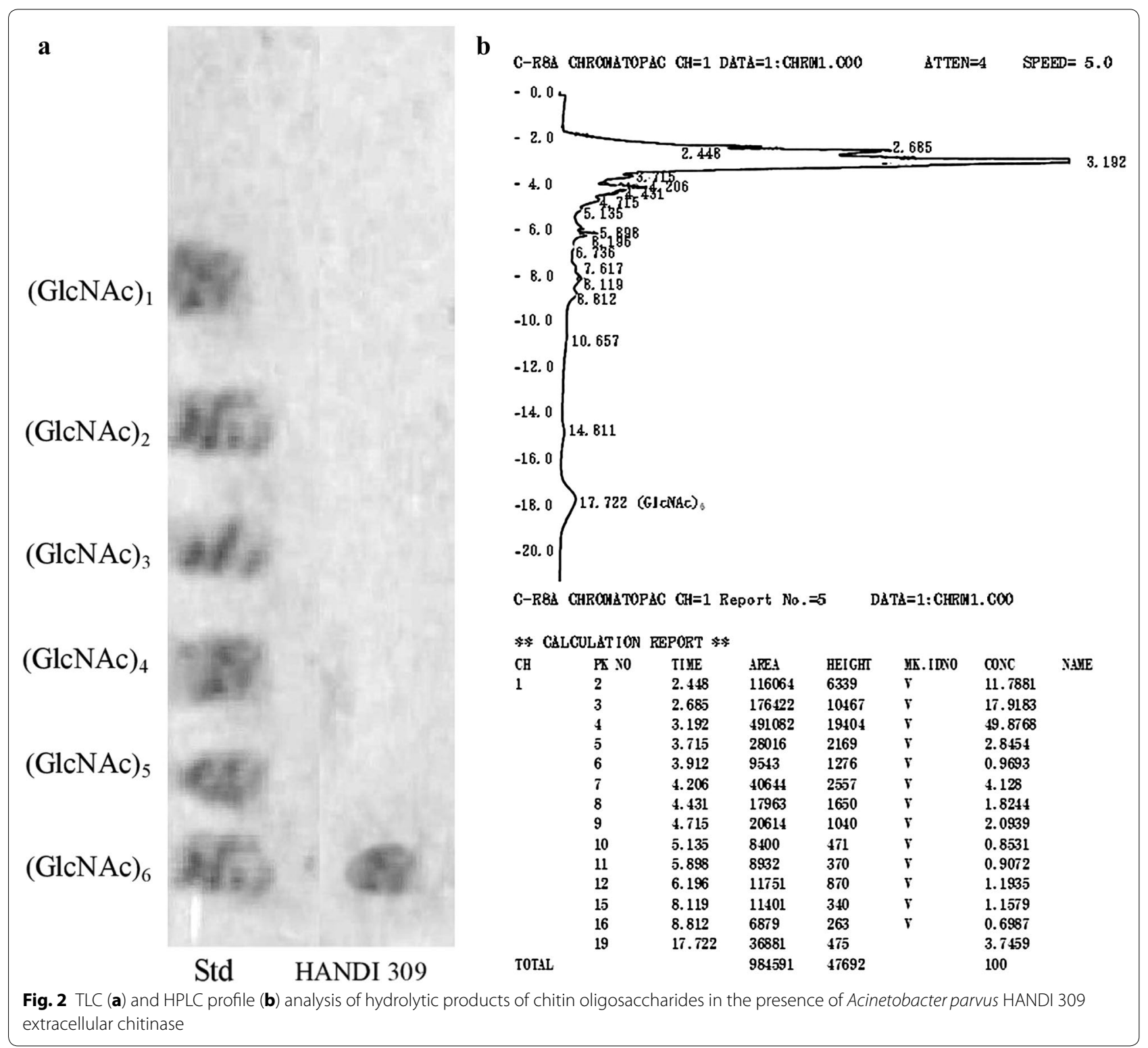



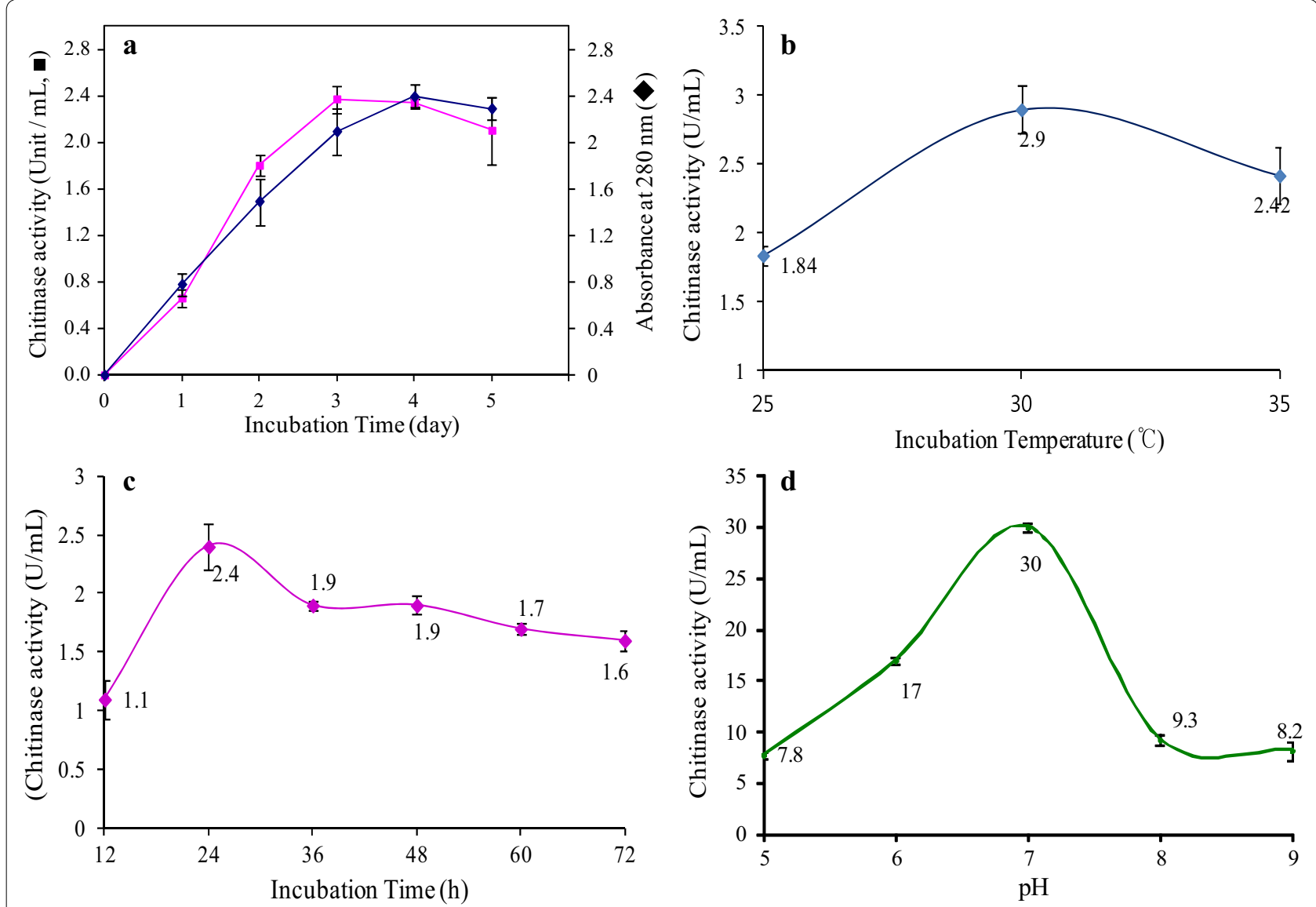

Fig. 3 Effect of the cell growth (a) incubation temperature $(\mathbf{b})$, time $(\mathbf{c})$ and $\mathrm{pH}$ (d) of the culture medium on A. parvus HANDI 309-produced exochitinase activity

that a novel $A$. parvus HANDI 309 biofuel had a greater efficiency to produce exo-chitinase for the production of $\mathrm{GlCNAc}_{6}$ on an industrial scale as compared with the production of $\mathrm{GlcNAc}_{6}$ from chitin by Aeromonas sp. GJ18-produced chitinase enzyme [15]. Similar results were shown by Nawani et al. [16], who reported that the chitinase activity correlated with the concentration of the swollen chitin. Also, the swollen chitin served as substrate or accumulation of chitin-decomposing intermediaries which served as a synthesis inhibitor of chitinases. The enzymatic reaction rate is directly proportional to the substrate concentration when at a low concentration. The greater concentration of the substrate has reduced the influence of the enzymatic reaction rate $[17,18]$.

\section{Effect of temperature, time and $\mathrm{pH}$ on chitinase activity}

In the bioprocess, temperature, time and $\mathrm{pH}$ are important environmental factors, which play a significant role in its regulation. Therefore, the bacteria growth and enzyme activity are also affected by changes in incubation temperature, time and $\mathrm{pH}$. Hence, we determined the optimum temperature, time and $\mathrm{pH}$ for the growth of bacteria and chitinolytic enzyme activity. Figure $3 \mathrm{~b}-\mathrm{d}$ exhibits the $A$. parvus HANDI 309-produced exo-chitinase activity optimum temperature $\left(30^{\circ} \mathrm{C}\right)$, time $(24 \mathrm{~h})$ and $\mathrm{pH}$ (7.0), respectively. This result was supported by Frandberg and Schniirer [19], who showed that the maximum activity of Bacillus pabuli $K 1$ is obtained at $30{ }^{\circ} \mathrm{C}$, whereas Bacillus pabuli $\mathrm{K} 1 \mathrm{did}$ not produce any chitinases at $10{ }^{\circ} \mathrm{C}$. Also, our results show that a novel A. parvus HANDI 309 biofuel had a greater efficiency to produce exo-chitinase as compared with the report of the production of $\mathrm{GlcNAc}_{6}$ from chitin by Aeromonas sp. GJ-18-produced chitinase enzyme [15]. From the above report, we have confirmed that a low temperature does not hamper the physiological functioning of the bacteria, including the enzymatic-concerning chitin. The present results concerning the time factor influencing chitinase activity point to the fact that $A$. parvus HANDI 309 underdetermination was able to decompose the maximum at $24 \mathrm{~h}$. The chitinolytic bacteria used the numerous carbon and nitrogen sources, but on the other 
hand reater amounts of accumulated chitin may slow down the further production of chitinases. From the above study, we have confirmed that the chitin decomposable compound and microorganisms need a shorter time to adapt to the substrate and become able to start the production of chitinases. The $\mathrm{pH}$ of the medium not only plays a significant role in the manufacture of chitinase but also helps with the cell growth. Many studies have reported that the maximum yield of chitinases enzymes obtained from bacteria is at neutral or slightly acidic $\mathrm{pH}$ condition [20]. By optimizing the high culture, the status has increased the production of chitinase at the end of the stage. The present study revealed that the A. parvus HANDI 309 culture could improve the production of different metabolites by adopting these culture conditions.

\section{Effect of carbon sources on chitinase activity}

Carbon sources act as major constituents for the activity of extracellular chitinase. The bacteria growth medium supplemented with four different carbon sources (1\%), glucose, sucrose, soluble starch and corn flour, were used to investigate the maximum chitinase production using swollen chitin as substrate. From the tested carbon sources, glucose supported the maximum extracellular chitinase activity from $A$. parvus HANDI $309(3.3 \mathrm{U} / \mathrm{mL})$ as compared with the other carbon sources of sucrose (3.0 U/mL), soluble starch $(2.9 \mathrm{U} / \mathrm{mL})$ and corn flour $(2.7 \mathrm{U} / \mathrm{mL})$, with the concentration of $0.5 \%$ of $A$. parvus HANDI 309 (Fig. 4a) enhancing the enzyme activity by acting as an inducer when also compared with sucrose, soluble starch and corn flour. The expression of chitinolytic chitinase is frequently induced by fungal cell wall components of glycoproteins and polysaccharides and reserved by carbon catabolic repressors of glucose and fructose [21]. The other supplements of swollen chitin such as chitin powder and chitin flakes are not an efficient source of swollen chitin, due to their colloidal nature. This present observation has been supported by Balakrishnan et al. [22] who obtained the maximum chitinase activity and protein content from Streptomyces sp. using $2 \%$ of sucrose.
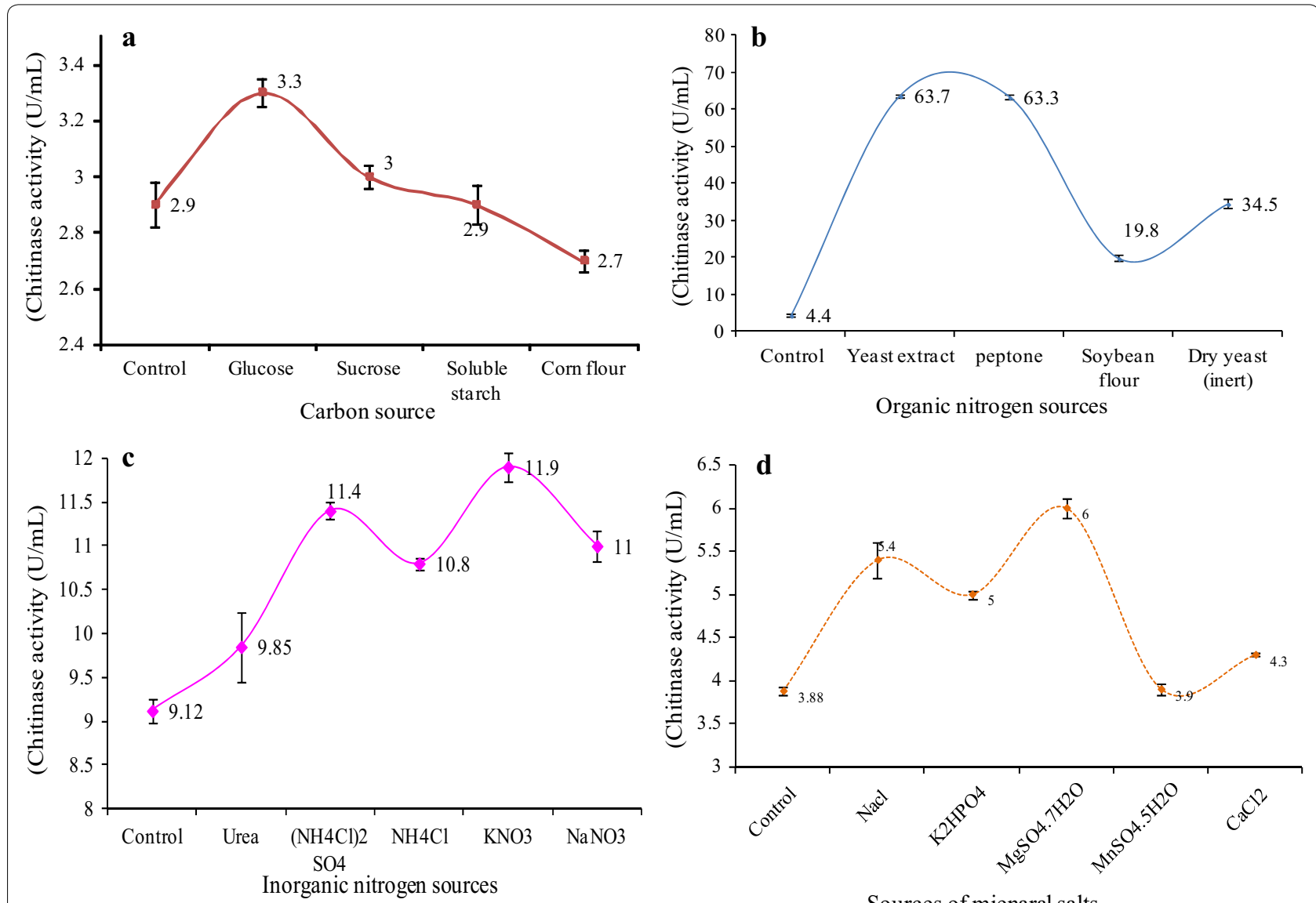

Sources of mienaral salts

Fig. 4 Effect of the carbon (a), organic (b), inorganic nitrogen (c) and mineral (d) sources of the culture medium on A. parvus HANDI 309-produced exo-chitinase activity 


\section{Effect of organic and inorganic nitrogen sources on chitinase activity}

Our results have shown the impact of various organic nitrogen sources on the activity of extracellular chitinase from $A$. parvus HANDI 309. Thus, the yeast extract exhibited the maximum chitinase activity of $63.7 \mathrm{U} / \mathrm{mL}$ when compared with the other nitrogen sources of peptone $(63.3 \mathrm{U} / \mathrm{mL})$, soybean flour $(19.8 \mathrm{U} / \mathrm{mL})$ and inert dry yeast $(34.5 \mathrm{U} / \mathrm{mL})$ with $A$. parvus HANDI 309 in the culture medium, and was improved with organic nitrogen sources such as $1 \%$ yeast extract (Fig. $4 \mathrm{~b}$ ) adjusted with concentrations of $0.05-2 \%$. This study supports the results of Tagawa and Okazaki [23] that yeast extract was a favourable supplement of the fermentation medium for the manufacture of polysaccharides, and of Suresh and Chandrasekaran [24] who also reported that yeast extract enhances the yield of enzyme production with the supplementation of phosphate. This finding significantly supports that by Priya et al. [25] who used various organic nitrogen sources like ammonium, sulfate, peptone, yeast extract, swollen chitin and malt extract, with swollen chitin exhibiting the maximum chitinase activity. Also, to conclude the effect of various inorganic nitrogen sources, such as urea, $\left(\mathrm{NH}_{4} \mathrm{Cl}\right)_{2} \mathrm{SO}_{4}, \mathrm{NH}_{4} \mathrm{Cl}, \mathrm{KNO}_{3}$ and $\mathrm{NaNO}_{3}$ used for the production of chitinase with $A$. parvus HANDI 309, $\mathrm{KNO}_{3}$ was the most favourable source and supported the maximum chitinase activity produced by $A$. parvus HANDI $309(11.9 \mathrm{U} / \mathrm{mL})$ as compared with urea $(9.85 \mathrm{U} / \mathrm{mL}),\left(\mathrm{NH}_{4} \mathrm{Cl}\right)_{2} \mathrm{SO}_{4}(11.4 \mathrm{U} / \mathrm{mL}), \mathrm{NH}_{4} \mathrm{Cl}$ $(10.8 \mathrm{U} / \mathrm{mL})$ and $\mathrm{NaNO}_{3}$, with the adjusted concentration of $\mathrm{KNO}_{3}[0.1 \%(\mathrm{w} / \mathrm{v})]$ (Fig. 4c). A greater activity of chitinase was developed by organic nitrogen compared with inorganic nitrogen. This is may be due to the presence of more amino acids and growth factors for bacteria growth which can be metabolized directly by cells. Hence, potassium nitrate can be an excellent alternative for the large-scale production of chitinase in industry.

\section{Effect of inorganic salts on chitinase activity}

Inorganic salts play a significant role in maintaining the cell growth, structure, configuration and activity of extracellular chitinase enzymes [26]. The activity of $A$. parvus HANDI 309 extracellular chitinase can be influenced by the presence of inorganic salt sources in the culture medium. Therefore, the effect of various inorganic salts on chitinase activity by $A$. parvus HANDI 309 was analyzed. The study result demonstrated the optimized concentration of inorganic salt which enhanced (Fig. 4d) the chitinase activity by incorporating the inorganic salt of $\mathrm{MgSO}_{4} \cdot 7 \mathrm{H}_{2} \mathrm{O}$ at $0.05 \%(\mathrm{w} / \mathrm{v})$ concentration as compared to other inorganic salts of $\mathrm{NaCl}(5.4 \mathrm{U} / \mathrm{mL}), \mathrm{K}_{2} \mathrm{HPO}_{4}$ $(5.0 \mathrm{U} / \mathrm{mL}), \mathrm{MgSO}_{4} 5 \mathrm{H}_{2} \mathrm{O}(3.9 \mathrm{U} / \mathrm{mL})$ and $\mathrm{CaCl}_{2}(4.3 \mathrm{U} /$
$\mathrm{mL}$ ). The enhancement of chitinase activity can be due to the presence of factors involving salts and enzyme production, which can ultimately lead to the chitinase activity. This study agreed with an earlier report wherein the results exhibited the agonist activity of $\mathrm{MgSO}_{4} \cdot 7 \mathrm{H}_{2} \mathrm{O}$ on the manufacture of chitinase enzyme by Pantoea dispersa and Streptomycetes [3, 27]. The present study has demonstrated that the extracellular chitinase from A. parvus HANDI 309 could be capable of industrial applications.

\section{Conclusion}

Extracellular chitinases play a crucial role in the pharmaceutical and biotechnological industries and especially in the production of fermented products. In conclusion, a novel bacterial strain of A. parvus HANDI 309 exo-chitinase can produce the $\mathrm{N}$-acetyl-D-glucosamine $(\text { GlcNAc })_{6}$ at an large-scale in short time. The isolated A. parvus HANDI 309 exo-chitinases have the potential to hydrolyze the chitin efficiently, and it has the capability to reach maximum production of $\mathrm{GlcNAc}_{6}$ in $24 \mathrm{~h}$ with the optimal temperature $30{ }^{\circ} \mathrm{C}$ and $\mathrm{pH} 7.0$ with carbon source glucose $0.5 \%$, yeast extract $1.0 \%$, inorganic nitrogen $\mathrm{KNO}_{3} 0.05 \%$, and inorganic salt $\mathrm{MgSO}_{4}$ $0.06 \%$. Therefore, these unique enzymatic properties of $A$. parvus HANDI 309 exo-chitinases can lead to the development of potentially low-cost alternatives in the pharmaceutical, food and biotechnological industries. In particular, further studies are needed to establish the low-cost, eco-friendly and effective biological method for the production of bioethanol from chitin by $A$. parvus HANDI 309 on an industrial scale.

\section{Additional files}

Additional file 1: Figure S1. Phylogenetic analysis based on $16 \mathrm{~S}$ rRNA gene sequences available from the National center for biotechnological information data library constructed after multiple alignments of data by ClustalX.

Additional file 2: Figure S2. Effect of glucose of the culture medium on the extracellular chitinase activity.

Additional file 3: Figure S3. Effect of yeast extract of the culture medium on the extracellular chitinase activity.

Additional file 4: Figure S4. Effect of $\mathrm{KNO}_{3}$ of the culture medium on the extracellular chitinase activity.

Additional file 5: Figure S5. Effect of magnesium sulfate of the culture medium on the extracellular chitinase activity.

\section{Abbreviations}

$\mathrm{CaCl}$ : Calcium chloride; $\mathrm{FeSO}_{4} \cdot 7 \mathrm{H}_{2} \mathrm{O}$ : Ferrous sulfate heptahydrate; GlcNAc: $N$-acetyl- $\beta$-D-glucosamine; HPLC: High-pressure liquid chromatography; $\mathrm{K}_{2} \mathrm{HPO}_{4}$ : Dipotassium hydrogen phosphate; KACC: Korean agricultural culture collection; $\mathrm{KH}_{2} \mathrm{PO}_{4}$ : Potassium dihydrogen phosphate; $\mathrm{MgSO}_{4} \cdot 7 \mathrm{H}_{2} \mathrm{O}$ : Magnesium sulfate heptahydrate; $\mathrm{NaNO}_{3}$ : Sodium nitrate; $\mathrm{NaOH}$ : Sodium hydroxide; TLC: Thin layer chromatography. 


\section{Authors' contributions}

TIK designed the study. KSK, SHC, KYK, and SKI conducted the experiments. DHL participated in experimental analysis. SMP participated in the sampling. BYP and MV analyzed the statistical data and prepared the manuscript. All authors read and approved the final manuscript.

\section{Author details}

${ }^{1}$ Dairy Science Division, National Institute of Animal Science, Rural Development Administration, \#114, Shinbang 1Gil, Seonghwan-eup, Seobuk-gu, Cheonan-si, Chungcheongnam-do 331-801, South Korea. ${ }^{2}$ Grassland and Forage Division, National Institute of Animal Science, Rural Development Administration, \#114, Shinbang 1Gil, Seonghwan-eup, Seobuk-gu, Cheonan-si, Chungcheongnam-do 331-801, South Korea.

\section{Acknowledgements}

This study was accomplished with the support of the "Cooperative Research Program for Agricultural Science and Technology Development" (Project title: Study on feeding management of Dairy Cattle in Alpine pasture; Project NoPJ010209032016, Rural Development Administration, Republic of Korea). This study is supported by the Postdoctoral Fellowship Program of National Institute of Animal Science, Rural Development Administration, Republic of Korea.

\section{Competing interests}

The authors declare that they have no competing interests.

\section{Availability of supporting data}

Data will be made available from the corresponding author on request.

\section{Funding}

This study was accomplished with the support of "Cooperative Research Program for Agricultural Science and Technology Development" (Project title: Study on feeding management of Dairy Cattle in Alpine pasture; Project NoPJ010209032016, Rural Development Administration, Republic of Korea).

\section{Received: 22 July 2016 Accepted: 21 February 2017}

Published online: 09 March 2017

\section{References}

1. Khoushab Y, Yamabhai M. Chitin research revisited. Mar Drug. 2010;8:1988-2012.

2. Dahiya N, Tewari R, Hoondal GS. Biotechnological aspects of chitinolytic enzyme: a review. Appl Microbiol Biotechnol. 2006;71:773-82.

3. Gohel V, Singh A, Vimal M, Ashwini P, Chhatpar HS. Review-bioprospecting and antifungal potential of chitinolytic microorganisms. Afr J Biotechnol. 2006;5:54-72.

4. Liang TW, Chen YJ, Yen YH, Wang SL. The antitumor activity of the hydrolyzates of chitinous materials hydrolyzed by crude enzyme from Bacillus amyloliquefaciens V656. Proc Biochem. 2007:42:527-34

5. Duo-Chuan L. Review of fungal chitinases. Mycopathologia. 2006:161:345-60.

6. Bhattacharya D, Nagpure A, Gupta RK. Bacterial chitinases: properties and potential. Crit Rev Biotechnol. 2007;27:21-8.

7. Chen JK, Shen CR, Liu CL. N-acetyl-D-glucosamine production and applications. Mar Drug. 2010;8:2493-516.

8. Sashiwa H, Fujishima S, Yamano N, Kawasaki N, Nakayama A, Muraki E, Sukwattanasinitt M, Pichyangkura R, Aiba S. Enzymatic production of $\mathrm{N}$-acetyl-D-glucosamine from chitin. Degradation study of $\mathrm{N}$-acetylchitooligosaccharide and the effect of mixing of crude enzymes. Carbohydr Polym. 2003;51:391-5.
9. Monreal J, Reese ET. The chitinase of Serratia marcescens. Cand J Microbiol. 1969;15:689-96.

10. Kim TI, Kwon EG, Kim HC, Cho YM, Park BK, Lee WK, Im SK. Screening and isolation of chitinase and chitosanase producing microbes from the feces of Korean native calves medicated DFMs including chitin. J Anim Sci Technol. 2009;51:387-94.

11. Miller GL. Use of dinitrosalicyclic acid reagent for determination of reducing sugar. Anal Chem. 1959;31:426-8.

12. Taechowisan T, Peberdy JF, Lumyoung S. Chitinase production by endophytic Streptomyces aureofaciens CMU Ac 130 and its antagonism against phytopathogenic fungi. Ann Microbiol. 2003;53:447-61.

13. Maria GL, Sridhar KR, Raviraja NS. Antimicrobial and enzyme activity of mangrove endophytic fungi southwest coast area. J Agric Technol. 2005;1:67-80

14. Thompson JD, Higgins DG, Gibson TJ, Clustal W. Improving the sensitivity of progressive multiple sequence alignment through sequence weighting, position-specific gap penalties and weight matix choice. Nucl Acid Res. 1994:22:4673-80

15. Kuk JH, Jung WJ, Jo GH, Kim YC, Kim KY, Park RD. Production of N-acetylD-glucosamine from chitin by Aeromonas sp. GJ-18 crude enzyme. Appl Microbiol Biotechnol. 2005;68:384-9.

16. Nawani NN, Kapadnis BP, Das AD, Rao AS, Mahajan RJ. Purification and characterization of thermophilic and acidophilic chitinase from Microbispora sp. V2. J Appl Microbiol. 2002;93:965-75.

17. Gupta R, Kumar S, Gomes J, Kuhad RC. Kinetic study of batch and fed batch enzymatic saccharification of pretreated substrate and subsequent fermentation to ethanol. Biotechnol Biofuels. 2012;5:1-10.

18. Kristensen $J B$, Felby $C$, Jorgensen $H$. Yield-determining factors in highsolids enzymatic hydrolysis of lignocelluloses. Biotechnol Biofuels. 2009;2:1-10.

19. Frandberg E, Schnurer J. Chitinolytic properties of Bacillus pabuli KI. J Appl Bacteriol. 1993;76:361-7.

20. Mathivanan N, Kabilan V, Murugesan K. Purification, characterization and antifungal activity of chitinases from Fusarium chlamydosporum, a mycoparasite to groundnut rust, Puccina arachidis. Can J Microbiol. 1998:44:646-51.

21. Donzelle ZGG, Lorito M, Scala F, Haraman GF. Cloning sequence and structure of a gene encoding an artificial glucan 1,3-glucosidase from Trichoderma atroviride. Gene. 2001;277:199-208.

22. Balakrishnan S, Duraisamy G, Manokaran K, Ganesan R, Chinthamani A, Chandrasekar U. Production, purification of chitinase by Streptomyces sp. from soil. J Adv Sci Res. 2012:3:25-9.

23. Tagawa K, Okazaki K. Isolation and some cultural conditions of Streptomyces sp. which produce enzymes lysing Aspergiluus niger cell wall. J Ferment Bioeng. 1991;71:230-6.

24. Suresh PV, Chandrasekharan M. Impact of process parameters on chitinase production by an alkaliphilic marine Beauveria bassiana in solidstate fermentation. Proc Biochem. 1999;34:257-67.

25. Priya CS, Jagannathan N, Kalaichelvan PT. Production of chitinase by Streptomyces hygroscopicus VMCH2 by optimization of cultural conditions. Int J Phar Bio Sci. 2011:2:210-9.

26. Madigan M, Martinko J. Brock biology of microorganisms. New Jersey: Prentice Hall; 2005

27. Han Y, Zhiyong L, Miao X, Zhang F. Statistical optimization of medium components to improve the chitinase activity of Streptomyces sp. Da11 associated with the South China Sea sponge Craniella australiensis. Proc Biochem. 2008:43:1088-93. 